\title{
PENGARUH MENGUNYAH PERMEN KARET TERHADAP PERISTALTIK USUS PASIEN POST APPENDIKTOMI
}

\author{
Grace Erlyn Damayanti S' ${ }^{1}$ Arfah May Syara ${ }^{2}$ \\ Dosen Fakultas Keperawatan dan Fisioterapi \\ Institut Kesehatan Medistra
}

\begin{abstract}
In the recovery period, the post appendicectomy intestinal peristalsis had not been reactivated normally. Because of these conditions, patients are advised not to eat and drink first for some time until the intestine activation back to normal. It is often complained by postoperative patients. In addition, surgery on the abdominal organs was no exception appendiktomy may caused paralytic ileus. This condition could inhibited or stopped the work of the intestine, cause pain, nausea, abdominal distension, and the patient must be hospitalized longer. Therefore action were needed that could accelerated the return of the patient's intestinal peristalsis. One of the interventions that could be done was to chew gum. This research was a quasi-experimental design with pre-test and post-test and use data analysis with paired sample $t$ test to test the entire population of post appendictomy patients in Grandmed Hospital of Lubuk Pakam. Sampling using total sampling with a significant level of $95 \%(p \leq 0,05)$. The results of this study indicate that there was effect of chewing gum on the peristalsis intestine of post appendictomy patients with $p$ value 0.000 . This suggests that there is the effect of chewing gum on the peristalsis intestine patients appendiktomi appendiktomi can improved the peristalsis intestine of post appendictomy patients in Grandmed Hospital of Lubuk Pakam. Based on the results of the study is expected to hospital and nurse to be able to make chewing gum into one of the interventions to accelerate the return of intestinal peristaltic post appendictomy patient.
\end{abstract}

Keywords: chewing gum, intestinal peristaltis

\section{PENDAHULUAN}

Appendiktomi menjadi salah satu jenis pembedahan abdomen akut yang paling sering dilakukan akibat serangan appendiksitis akut. Hal ini mungkin terkait dengan diet serat yang kurang pada masyarakat modern (perkotaan) bila dibandingkan dengan masyarakat desa yang cukup banyak mengkonsumsi serat (Mansjoer, 2010).

Data dari World Health Organization (WHO) menyebutkan bahwa appendiktomi dilakukan pada $4,8 \%$ dan $2,6 \%$ dari total populasi penduduk Asia dan Afrika yang menderita apendisitis. Di Amerika sekitar $7 \%$ penduduk menjalani apendiktomi dengan insidens $1,1 / 1000$ penduduk pertahun, sedang di Negara-Negara barat sekitar $16 \%$.

Berdasarkan hasil Survei Dinas Kesehatan di Indonesia, appendicitis akut merupakan salah satu penyebab dari akut abdomen dan berupa indikasi untuk dilakukan operasi kegawat daruratan. Di beberapa Kota Indonesia yaitu kota Semarang, yakni 970 orang menjalani appendiktomi, kota Gorontalo, 
di peroleh data dari Sub Bagian Medikal Record bahwa jumlah pasien yang melakukan tindakan operasi appdendiktomi pada tahun 2014 dari sekitar 1606 pasien bedah umum, sebanyak 576 pasien diantaranya yang melakukan operasi appendiktomi atau sekitar $35,87 \%$ pada tahun 2014 . Pada tahun 2015, dari 1.431 pasien bedah umum sebanyak 455 diantaranya yang melakukan operasi appendiktomi atau sekitar $31,79 \%$. Hal ini bisa terjadi karena diet serat yang kurang pada masyarakat moderen sehingga mengakibatkan penyakit yaitu appendicitis.

Pada appendiktomi, pasien diberikan anestesi yang berefek terhadap relaksasi otot-otot khususnya terjadi penurunan peristaltik usus. Pada keadaan pasca operasi tanpa komplikasi, normalnya peristaltik usus kembali \pm 24 jam pasca operasi (Mansjoer, 2010).

Dalam masa pemulihan, peristaltik usus pasien post appendiktomi belum aktif kembali secara normal. Karena keadaan tersebut, pasien dianjurkan untuk tidak makan dan minum terlebih dahulu selama beberapa waktu hingga aktifasi usus kembali seperti semula. Hal tersebut sering dikeluhkan oleh pasien post operasi. Selain itu operasi pada organ abdomen tidak terkecuali appendiktomi dapat menyebabkan ileus paralitik. Kondisi ini dapat menghambat atau menghentikan kerja dari usus, menimbulkan rasa nyeri, mual, distensi abdomen, serta semakin lama pasien harus dirawat di rumah sakit. Lamanya pasien tinggal di Rumah sakit akan menyebabkan tingginya resiko infeksi dan mahalnya biaya perawatan (Majid dkk, 2011). Oleh karena itu diperlukan tindakan yang dapat mempercepat kembalinya peristaltik usus pasien. Salah satu intervensi yang dapat dilakukan adalah dengan mengunyah permen karet.

Penelitian yang dilakukan Effendi (2015) yang meneliti mengenai pengaruh mengunyah permen karet terhadap percepatan kembalinya peristaltik usus pada pasien pasca appendiktomi didapatkan pada kelompok perlakuan menunjukan peristaltik usus timbul 1 jam ke-3 sejumlah 1 orang (20\%), peristaltik usus timbul 1 jam ke-4 sejumlah 2 orang (40\%) dan peristaltik usus timbul 1 jam ke-5 sejumlah 2 orang (40\%) sedangkan pada kelompok kontrol menunjukan 5 orang $(100 \%)$ peristaltik muncul setelah 1jam ke-5. Hasil uji statistik didapatkan ada pengaruh mengunyah permen karet dengan percepatan peristaltik usus. Percepatan peristaltik usus pada pasien pasca appendiktomi dapat dilakukan dengan upaya mengunyah permen karet.

Penelitian yang dilakukan oleh Jaimez dan Garcia (2016) juga mendapatkan bahwa penggunaan permen karet pada anak yang menjalani appendiktomi dapat mempercepat kembalinya fungsi usus. Didukung juga oleh penelitian yang dilakukan oleh Ajuzieogu, et al. (2014) yang mendapatkan bahwa memakan permen karet memberikan efek yang menguntungkan terhadap cepatnya kembali fungsi usus.

Dari hasil studi pendahuluan yang didapatkan dari Rumah Sakit Grandmed Lubuk Pakam perawat hanya mengobservasi waktu kembalinya peristaltik usus pada pasien post appendiktomi namun belum ada tindakan khusus untuk mempercepat kembalinya peristaltik usus pada pasien pasca appendiktomi. Atas dasar itu peneliti tertarik untuk meneliti pengaruh mengunyah permen karet terhadap 
peristaltik usus pasien appendiktomi di Rumah Sakit Grandmed Lubuk Pakam.

\section{METODE PENELITIAN}

Desain penelitian yang digunakan adalah pre test and post test design. Penelitian ini dilakukan di Rumah Sakit Grandmed Lubuk Pakam pada bulan Januari-Juni 2018 dengan jumlah populasi 47 orang. Teknik sampling yang digunakan pada penelitian ini adalah total sampling. Instrumen pada penelitian ini adalah lembar checklist yang berisi tentang frekuensi peristaltik usus pasien.

Analisis univariat digunakan untuk melihat rerata frekuensi peristaltik usus sebelum dan sesudah mengunyah permen karet, sementara analisis bivariat dilakukan untuk melihat pengaruh mengunyah permen karet terhadap peristaltik usus yang di uji menggunakan paired sample $t$ test dengan tingkat kepercayaan $95 \%$.

\section{HASIL DAN PEMBAHASAN}

Tabel 1. Rerata Frekuensi Peristaltik Usus Pasien Post Appendiktomi Sebelum Mengunyah Permen Karet di Rumah Sakit Grandmed Lubuk Pakam

\begin{tabular}{lllll}
\hline \multicolumn{1}{c}{ Kategori } & $\mathrm{N}$ & Mean & $\begin{array}{c}\text { Std. } \\
\text { Deviat } \\
\text { ion }\end{array}$ & $\begin{array}{c}\text { Std. } \\
\text { Error } \\
\text { Mean }\end{array}$ \\
\hline $\begin{array}{l}\text { Peristaltik } \\
\text { Usus }\end{array}$ & 47 & 1,00 & 1,155 & 0,365 \\
$\begin{array}{l}\text { Sebelum } \\
\text { Mengunyah }\end{array}$ & & & & \\
Permen Karet & & & & \\
\hline
\end{tabular}

Rerata frekuensi peristaltik usus pasien post appendiktomi sebelum mengunyah permen karet adalah 1,00 dengan standard deviasi 1,155 dan standard error mean sebesar 0,365.
Pada penelitian ini seluruh responden menggunakan anastesi spinal sehingga jenis anastesi yang digunakan sudah homogen. Anastesi merupakan manipulasi organ yang dilakukan selama prosedur pembedahan. Efek anastesi dapat menyebabkan selama 24 sampai 48 jam, sesuai jenis dan lamanya pembedahan sehingga peristaltik usus tidak terdengar ataupun dapat terdengar lemah dengan frekuensi yang kurang dari normal (Smeltzer \& Bare, 2013). Pada penelitian ini didapatkan rerata peristaltik usus sebelum mengunyah permen karet hanya 1,00 kali, sedangkan rata-rata normal bising usus adalah 6-12 kali per menit.

Tabel 2. Rerata Frekuensi Peristaltik Usus Pasien Post Appendiktomi Sesudah Mengunyah Permen Karet di Rumah Sakit Grandmed Lubuk Pakam

\begin{tabular}{lcccc}
\hline \multicolumn{1}{c}{ Kategori } & $\mathrm{N}$ & Mean & $\begin{array}{c}\text { Std. } \\
\text { Devia } \\
\text { tion }\end{array}$ & $\begin{array}{c}\text { Std. } \\
\text { Error } \\
\text { Mean }\end{array}$ \\
\hline $\begin{array}{l}\text { Peristaltik } \\
\text { Usus }\end{array}$ & 47 & 7,60 & 1,578 & 0,499 \\
$\begin{array}{l}\text { Sesudah } \\
\text { Mengunyah }\end{array}$ & & & & \\
Permen & & & & \\
Karet & & & & \\
\hline
\end{tabular}

Rerata frekuensi peristaltik usus pasien post appendiktomi sesudah mengunyah permen karet adalah 7,60 dengan standard deviasi 1,158 dan standard error mean 0,499.

Pada penelitian ini pasien mengunyah permen karet sebanyak 3 kali selama 30 menit. Menurut Ledari (2013), Ketika mengunyah permen karet maka pasien akan merasakan reaksi yang disebabkan oleh stimulasi abdomen serta sekresi dari getah lambung dan usus. Hal ini akan menyebabkan pasien berkeinginan 
untuk makan. Keinginan ini akan meningkatkan peristaltik dan mempercepat proses pemulihan ileus. Pada hasil penelitian ini didapatkan eningkatan rerata peristaltik usus dimana sebelum mengunyah permen karet rerata peristaltik usus sebesar 1,00 kali dan setelah mengunyah permen karet didapatkan rerata peristaltik usus sebesar 7,60 kali.

Tabel 3. Pengaruh Mengunyah Permen Karet Terhadap Peristaltik Usus Pasien Post Appendiktomi di Rumah Sakit Grandmed Lubuk Pakam

\begin{tabular}{lcccc}
\hline \multicolumn{1}{c}{ Kategori } & N & Mean & $\begin{array}{c}\text { Std. } \\
\text { Deviation }\end{array}$ & $\begin{array}{c}\text { P } \\
\text { value }\end{array}$ \\
\hline Peristaltik & 47 & 6,600 & 1,265 & 0,000 \\
Usus Sesudah & & & & \\
Mengunyah & & & & \\
Permen Karet & & & \\
$\& \quad$ Peristaltik & & & \\
Usus Sebelum & & & \\
Mengunyah & & & \\
Permen Karet & & & \\
\hline
\end{tabular}

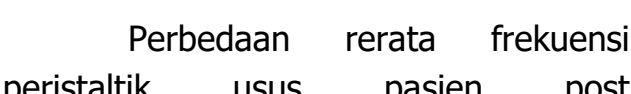
appendiktomi sebelum dan sesudah mengunyah permen karet adalah 6,60 dengan perbedaan standard deviasi 1,265. Berdasarkan uji statistik didapatkan $p$ value 0,000 , maka ada pengaruh mengunyah permen karet terhadap peristaltik usus pasien post appendiktomi di Rumah Sakit Grandmed Lubuk Pakam.

Penelitian menunjukkan bahwa peristaltik usus muncul lebih cepat pada kelompok yang mengunyah permen karet yaitu pada 1 jam ke-3, sedangkan pada kelompok kontrol peristaltik usus muncul pada 1 jam ke-5. Dari hasil peneltian tersebut dapat disimpulkan bahwa ada pengaruh mengunyah permen karet dengan percepatan peristaltik usus (Effendi, 2015).

Penelitian yang dlakukan oleh Jaimez dan Garcia (2016) pada kelompok anak yang menjalani appendiktomi juga mendapatkan bahwa penggunaan permen karet dapat mempercepat kembalinya fungsi usus. Anak yang mengunyah permen karet setelah operasi, bising usus kembali lebih cepat. Hal yang sama didapatkan oleh Ajuzieogu, et al. (2014) dimana penelitian ini menyimpukan bahwa memakan permen karet memberikan efek yang menguntungkan terhadap cepatnya kembali fungsi usus.

Bagaimana mekanisme hubungan cantara mengunyah permen karet dan kembalinya peristaltik usus setelah tindakan operasi belum dapat dijelaskan dengan pasti. Penjelasan yang paling mungkin adalah bahwa mengunyah berfungsi sebagai Sham Feeding, stimulasi motilitas usus, duodenum, dan rektum di perut manusia. Mengunyah dapat memicu pelepasan hormonhormon gastrointestinal dan meningkatkan sekresi saliva serta cairan getah pankreas, gastrin, dan neurotensin. Pelepasan hormon-bormon tersebut dapat memicu perisstaltik usus (Ledari, 2013).

Semakin cepat peristaltik usus kembali setelah prosedur operasi maka akan sangat bermanfaat dalam proses pemulihan pasien. Kembalinya peristaltik usus menjadi tanda bahwa pasien sudah boleh mendapatkan intake oral. Semakin cepat pasien makan, maka akan semakin cepat terpenuhi kebutuhan nutrisi yang akan mendukung terhadap penyembuhan lluka operasi dan pemulihan fisik post operasi. Hal ini akan menurunkan lama rawat inap pasien di rumah sakit. Sehingga lebih ekonomis, dan mengurangi risiko infeksi 
nosokomial yang didapat dari lingkungan rumah sakit (Marwah, 2012).

\section{KESIMPULAN}

Berdasarkan penelitian yang dilakukan didapatkan rerata peristaltik usus pasien post appendiktomi sebelum mengunyah permen karet adalah 1,00 dan sesudah mengunyah permen karet adalah 7,60. Perbedaan rerata peristaltik usus pasien post appendiktomi sebelum dan sesudah mengunyah permen karet adalah 6,60. Dari hasil uji statistik didapatkan ada pengaruh mengunyah permen karet terhadap peristaltik usus pasien post appendiktomi di Rumah Sakit Grandmed Lubuk Pakam dengan $p$ value $=0,000$.

\section{DAFTAR PUSTAKA}

Ajuzieogu, et al. (2014). The efficacy of chewing gum on postoperative ileus following appendictomy in Enugu, South East Nigeria: $A$ randomized controlled clinical trial. Nigerian Journal of Clinical Practice. Volume 17, issue 6, 739-742 Diunduh dari https://www.ncbi.nlm.nih.gov/ pubmed/25385912 pada tanggal 21 Desember 2017.

Effendi (2015). Pengaruh Mengunyah Permen Karet Terhadap Percepatan Kembalinya Peristaltik Usus Pada Pasien Pasca Appendiktomi. Jurnal Kesehatan Hesti Wira Sakti. Vol 3. No 2. Diunduh dari http://jurnal.poltekkessoepraoen.ac.id/index.php/HW S/article/view/101 pada tanggal 21 Desember 2017.

Majid, A., Mohamad, J dan Umi, I. (2011). Keperawatan Perioperatif. Yogyakarta : Gosyen Publishing

Jaimez \& Garcia. (2016). Use of chewing gum in children undergoing an appendectomy: $A$ randomized clinical controlled trial. Int J Surg. 2016 Aug;32:38-42. Diunduh dari https://www.ncbi.nlm.nih.gov/ pubmed/27321384 pada tanggal 21 Desember 2017.

Ledari, FM, et al. (2013). Chewing Cugar-Free Gum Reduces Ileus After appendectomy : $A$ Rondomized Cilnical Trial. Iranian Red Crescent Medical Journal. 2013; 15 (4): 330-4.

Mansjoer, Arief (2010), Kapita Selekta Kedokteran, edisi 4, Jakarta : Media.

Marwah, S et al. (2012). Role of Chewing Gum on The Duratin of Post Operative Ileus Following Illeostomy Closure Done for Typhoid Illeal Perforation: A Prospective Randomized Trial. Saudi Journal of Gastroenterologi Volume 18 Number 2.

Smeltzer S. C., Bare G. B. (2013). Buku Ajar Keperawatan Medikal Bedah, Edisi 8 Volume 1. Jakarta: EGC 